Marquette University

e-Publications@Marquette

4-2021

Metaphysics Supervenes on Logic: The Role of the Logical Forms in Hegel's "Replacement" of Metaphysics

W. Clark Wolf

Follow this and additional works at: https://epublications.marquette.edu/phil_fac

Part of the Philosophy Commons 


\title{
Metaphysics Supervenes on Logic: The Role of the Logical Forms in Hegel's "Replacement" of Metaphysics
}

\author{
W. CLARK WOLF*
}

\begin{abstract}
In this paper, I seek to explain Hegel's view that his "logic" replaces metaphysics. I argue that Hegel's discussion of logical forms of judgment and syllogism in book III of The Science of Logic is meant to be the foundation of his reformation of metaphysics. Implicit in Hegel's discussion of the logical forms is the view that the metaphysical concepts discussed in books I and II of the Logic supervene on the role of subject and predicate terms in the logical forms discussed in book III. Hegel thus has an explanation for the nature and significance of metaphysical concepts that resembles Kant's "metaphysical deduction." In addition to illustrating the dependence of metaphysics on logic, the present interpretation provides a new picture of the structure of Hegel's Logic that emphasizes the explanatory priority of its Doctrine of the Concept.
\end{abstract}

KEYWORDS Hegel, Science of Logic, logic, metaphysics, supervenience, Kant, rationalism

Logic is to us a natural metaphysic. Anyone who thinks, has it. (GW 23:I, I9)

\section{I N T R O D U C T I O N}

AS IS COMMONLY RECOGNIZED, only a small portion of Hegel's Science of Logic looks anything like a logic in the normal sense, namely, a work that considers forms of judgment and rules of inference. For this reason, when Hegel says that his Logic "replaces" or "coincides" with metaphysics, ${ }^{2}$ this apparently does not imply that

II will use 'Logic' in general to refer to the combined project of The Science of Logic (the "Greater Logic") and the Encyclopedia Logic (the "Lesser Logic"). These will be cited as SL and EL respectively.

${ }^{2}$ E.g. "Thus logic coincides with metaphysics, the science of things grasped in thoughts that used to be taken to express the essentialities of the things" (W 8:8I/EL \$24). "If we look at the final shape in

*W. Clark Wolf is a visiting assistant professor at Marquette University.

Journal of the History of Philosophy, vol. 59, no. 2 (202I) 27I-98 
formal or informal logic, or a special kind of "dialectical logic," is supposed to replace metaphysics. ${ }^{3}$ Indeed, when we consider the contents of The Science of Logic superficially, the air of paradox over this "logic" replacing metaphysics should diminish considerably. For the first part of Hegel's Logic, the so-called Objective Logic, is intended transparently as a critical account of the most general pure concepts. As Hegel himself avows, this project largely coincides with what was then called "ontology" in the rationalist tradition of Christian Wolff and Alexander Baumgarten. ${ }^{4}$ Namely, Hegel's Logic treats many of the same pure concepts as traditional metaphysics, so much so that it has been rightly claimed "there is hardly a single category to be found [in Hegel's Logic] which Wolff had not discussed-in his own way, of course-in his Ontology." It is of course possible to "replace" one thing with more of the same kind. But presumably Hegel intends such claims about the replacement of metaphysics to mean something more than that he offers a different and superior system of metaphysical concepts in the traditional sense. ${ }^{6}$

However, the specifically logical dimension of Hegel's Logic has not typically been brought to bear on this issue. Indeed, it has been so neglected that the question of the connection of the Logic to metaphysics has been frequently reduced to the question of the relation of "thought" and "being." 7 This tendency poses the problem of Hegel's metaphysics not as internal to Hegel's first-level argumentation in the Logic, but at a second level. Here, Hegel's metaphysics is supposed to consist in his view about how the conceptual work of the Logic relates to the world or "being" outside of it. ${ }^{8}$ Hegel's metaphysics is, as it were, about, not in, the Logic. Taking as given Hegel's internal conceptual arguments, is he "ambitious" or

the elaboration of this science, then it is ontology which objective logic most directly replaced in the first instance, that is, the part of metaphysics intended to investigate the nature of ens in general (and ens comprises within itself both being and essence, a distinction for which the German language has fortunately preserved different expressions)" (W 5:6I/SL 42). Throughout the article, emphasis is in the original unless otherwise noted.

${ }^{3}$ See Beiser, Hegel, I6I-62; Pippin, Shadows, 69-70; and Redding, "Role."

${ }^{4}$ See the second quotation in note 2 above.

${ }^{5}$ Erdmann, Leibnitz und die Entwicklung, 289. (This and other translations from German secondary literature are my own.) Bubner similarly writes that Hegel's Logic is designed "to provide an intrinsically coherent and interconnected articulation of the totality of all previously generated concepts [of metaphysics]. Hegel's Logic thus methodologically reinterprets the entire history of metaphysics" (Innovations of Idealism, 66).

${ }^{6}$ Cf. Pippin's remarks on "replacing" or "taking the place of" in Shadows, I $28 \mathrm{n}_{5} 6$.

${ }^{7}$ See especially Houlgate, Opening, chap. 6. Redding treats the problem of logic and ontology in Hegel as one of determining "content" from the logical resources of negation in particular: "Hegel's task is to, in some sense, derive what is taken to be his organic metaphysics from the immanent development of a content for logic" ("Relation," I 59, emphasis added). It is objective conceptual content that stands in for "ontology" on Redding's view: "Such would be Hegel's starting point, and the task of getting an ontology out of logic would proceed by a process of making such initially indeterminate content determinate" ("Relation," I 5 I). Redding does not mean by 'content' here what I will call "logical content" below. Nor does this use of 'ontology' map on to the pre-Kantian rationalist conception.

${ }^{8}$ See Houlgate, Opening, I 20-26; Redding, "Relation," I64. The same could be said of Pippin's earlier "antirealistic" approach in Hegel's Idealism: "Hegel also states that reality is the developing Notion, and this certainly suggests a kind of contemporary antirealism, a relativization of truth claims to the Hegelian (Notional) equivalent of something like warranted assertability, or provability, or membership in an ideal theory" (99). Namely, Pippin has also tended to locate the metaphysical problem of Hegel's Logic in the relation of thought and being, only to emphasize in various ways how Hegel's account of conceptuality obviates any ultimate gap between it and reality. 
"modest" about the objective significance of this system of concepts? So runs the debate. One gets the impression that Hegel's metaphysics is, after all, a matter of his temperament, since the same conceptual content could appear unchanged within either an ambitious or modest project. And since this way of framing the debate concerns the external significance of the Logic as a whole, it does not shed much light on the specific relevance of logic to metaphysics within the work.

Though the consensus that Hegel's Logic is not meant as a normal work of logic is correct enough, it has led to a marginalization of the portion of the work that deals explicitly with logical forms. This has been a missed opportunity to explain Hegel's unique conception, not only of logic, but of metaphysics as well. As I hope to show, Hegel's treatment of logical forms contains an argument, internal to the work, about the relationship of logic in a more ordinary sense and metaphysical concepts. I wish to show how Hegel's claim that logic replaces metaphysics can be explained by considering the relation between the transparently metaphysical concepts of the Logic and the transparently logical ones. Hegel discusses, and usually criticizes, transparently metaphysical concepts in the "Objective Logic," the Doctrine of Being and the Doctrine of Essence. These are concepts such as $<$ being $>$, <quality $>$, <quantity $>$, <essence $>$, < appearance $>$, and $<$ ground $>.{ }^{9}$ Logical concepts and forms are discussed in the first part of the "Subjective Logic," or the Doctrine of the Concept (Begriffslogik).$^{\text {Io }}$ Here one finds discussion of topics like conceptual universality, disjunctive judgments, and analogical syllogisms. The two main divisions of the Logic may appear not to have much in common. Yet Hegel says a number of things that suggest that the Begriffslogik plays a foundational role with respect to the Doctrines of Being and Essence. In what follows, I will emphasize the significance of the logical forms of concept, judgment, and syllogism for Hegel's critique of metaphysics. I am not aware of a treatment that explains the dependence of the Objective Logic on the Subjective Logic in this way. ${ }^{\text {II }}$ It is the foundational role of these logical forms for metaphysical concepts (as well as his belief that they are nevertheless "untrue") that separates Hegel's explanation of metaphysics from those of his pre-Kantian predecessors. Thus, Hegel's Logic embodies a thesis about the logical "origin" of metaphysical concepts. To put the thesis in a slogan, I will argue that, for Hegel, metaphysical concepts supervene on logical forms. This thesis is "embodied" in the Logic because it is shown more than told. It is the aim of this essay to tell how Hegel shows it.

${ }^{9}$ Angled brackets $('<\ldots>>$ ') indicate that a concept is being referred to. (See e.g. Anderson, Poverty of Conceptual Truth, for a precedent.) The convention is important in many cases, since according to the reading adopted here, Hegel may be explicating a concept without being committed to its referent. For example, a discussion of <property $>$ may or may not imply a commitment to properties so described. On the other hand, Hegel is not merely discussing the use of the word, e.g. 'property.'

${ }^{10}$ These terms for the Doctrine of the Concept will be used interchangeably throughout.

${ }^{11}$ As Robert Pippin has recently remarked, "To understate the matter in the extreme: this book [i.e. The Science of Logic] still awaits its full contemporary reception" (Shadows, 4). This holds especially of the logical portion of the Subjective Logic, despite some good studies in recent years: see e.g. Hanna, "Ontological"; Redding, Return, "Role," and "Subjective"; Sans, Realisierung; and Schick, Wissenschaft, "Mangel," and "Die Lehre." However, I do not think the relation between the logical forms and the metaphysical concepts of the Objective Logic has been adequately treated. Gerhard, Frage, shows how the discussion of logical forms is connected to "Objectivity" within the Begriffslogik, though she does not devote much attention to the relation of the Subjective to the Objective Logic, as I do here. 
The thesis that metaphysical concepts supervene on logical forms-which I will call simply the "supervenience thesis" — has much in common with Kant's view that the categories can be derived from the forms of judgment, announced in his so-called Metaphysical Deduction of the Categories. The affinity between Hegel's approach to metaphysics and this Kantian view has been recently emphasized especially by Robert Pippin. ${ }^{\mathrm{I} 2}$ However, in Kant's case, the Metaphysical Deduction leads to specific claims about the connection of metaphysical concepts and principles to the forms of judgment (combined with the forms of intuition). For example, the causal principle is linked to the hypothetical judgment. Though Pippin and others have drawn attention to the affinity of Hegel's Logic with Kantian transcendental logic, they have not shown how this connection can be explained in fine, namely, that each metaphysical concept has its origin in a different logical form. As far as I know, only Robert Brandom has attributed a similar view to Hegel, though primarily in the context of the Phenomenology. ${ }^{\mathrm{I3}}$ In my view, it is in the logical portion of the Logic that such a view attains its most systematic presentation.

I will begin by presenting some passages from Hegel's Logic concerning the general structure of that work (section 2). They claim in general terms that the Doctrine of the Concept plays a theoretically foundational role for the rest of the Logic. These passages provide an interpretative explanandum. Since I argue that Hegel's conception of logical forms explains the dependence of the Objective Logic on the Begriffslogik, I then explain how Hegel's treatment of the logical forms does not amount to a general or formal logic, and that his conception of logic is at odds with the traditional notion of general logic (section 3 ). Hegel's key innovation is his idea that every form of judgment and syllogism must be presented as having some variety of "logical content." In section 4, I argue that Hegel uses his notion of logical content to demonstrate the supervenience thesis: the view that metaphysical concepts supervene on logical forms. This implies that the treatment of logical forms in the Begriffslogik is meant to explain the existence (though not, in general, the correctness) of the metaphysical concepts of the Objective Logic. In section 5, I offer a few representative examples of the supervenience thesis. Finally, I assess the significance of the supervenience thesis for the interpretation of Hegel's metaphysics in general.

\section{THE PRIORITY OF THE DOCTRINE OF THE CONGE T I N HEGEL'S LOGIC}

In this section, I outline a view about the role of the Doctrine of the Concept, and especially its treatment of logical forms, within the whole of The Science of Logic. This

\footnotetext{
${ }^{\mathrm{I}}$ See Pippin, Shadows, 40, 62-65, 80-8I.

${ }^{13}$ Brandom claims that Hegelian philosophical concepts are "pragmatic metaconcepts" that "play the special expressive role of making explicit what is implicit in the use and content of ordinary empirical and practical concepts" (Spirit, 8). He elsewhere (i.e. "Metaphilosophical Reflections," 25-26) associates these pragmatic metaconcepts or "metavocabulary" with the project of metaphysics. Though Brandom does not present a Hegelian pragmatic metavocabulary systematically, his view also suggests that for Hegel different kinds of logical doings-ways to judge or infer-would require different metaconceptual-and so metaphysical- "sayings." See Spirit, I03, 208-9. Stekeler-Weithofer (Kritik, chap. I6) also offers a picture of the relationship of logic and metaphysics that resembles the one here, though it is not defended exegetically.
} 
view responds to a series of passages that have been neglected by commentators. It also provides a specific explanation of Hegel's claims about Kant as setting a precedent for his treatment of metaphysics.

\section{I. The Doctrine of the Concept as Foundation}

In many places, Hegel alludes to the fact that the Doctrine of the Concept, despite being the final part of the work, plays a special foundational role with respect to the rest of the Logic. Though these passages are often obscure by themselves, together they provide an important explanandum for the thesis I will defend. Here are some key passages:

Now the concept is to be regarded indeed, not just as a subjective presupposition but as absolute foundation; but it cannot be the latter except to the extent that it has made itself into one.... Being and essence are therefore moments of [the concept's] becoming; but the concept is their foundation and truth as the identity into which they have sunk and in which they are contained. (W 6:245/SL 508)

The concept has subjugated the spheres of being and essence to which, from other starting points, feeling, intuition, and representation . . . also belong; it has demonstrated itself to be their unconditional foundation [unbedingten Grund]. But this is one side alone. There is a second side left to which this third book of the Logic is devoted, namely the demonstration of how the concept forms within and from itself the reality that has vanished in it. (W 6:263/SL 522)

The concept is the truth of the substantial relation in which being and essence attain their perfect self-subsistence and determination each through the other. (W 6:269/SL 526)

It is precisely the Concept that contains [enthält in sich] all the earlier determinations of thinking sublated within itself. ... [T] he Concept is also what is utterly concrete, precisely because it contains Being and Essence, and hence all the riches of both these spheres, within itself in ideal unity. (W 8:307-8/EL §I6०Z)

These passages are in agreement that "the concept" (der Begriff) plays an important role vis-à-vis "being" and "essence": it is their "foundation" and "truth," or it "contains" them. Though one might try to find in the above passages expressions of an emanationist metaphysic, I think it is clear in most of the above quotations that Hegel is not referring to "the concept" as an entity, nor to "being" and "essence," taken de re. He refers (by metonymy) first and foremost to the "spheres" ${ }^{\text {I4 }}$ of the Doctrines of Being, Essence, and Concept, and the "determinations" that make up these spheres. These passages thus claim that the Doctrine of the Concept is theoretically foundational for the rest of the work, however things stand metaphysically. It is in terms of theoretical content that the Begriffslogik can be said to contain "all the riches" of the Objective Logic.

It is not obvious on the face of it how this could be, especially considering the apparent poverty of the first sections of the Doctrine of the Concept. Given the blatantly logical content of these sections, it is more traditional to see the content

${ }^{14}$ Some of the passages above do not use 'sphere'; it is the translator's interpretation. Yet Hegel often uses this term in this way, so it is not an implausible clarifying insertion. See e.g. EL §I6IZ, §I65R; W 6:279, 3I2, 335 . Citations of Encyclopedia material may include references to Zusätze ('Z') from Hegel's lecture material, or Remarks ('R'). 
of the Begriffslogik as drawn from the riches of the Objective Logic. Let us call this the continuity view. This approach sees the Subjective Logic as continuing the same kind of metaphysical project as the Objective Logic. For example, on this reading, the metaphysical concept $<$ substance $>$, the final topic of Essence, presents the high point of metaphysical speculation, corresponding roughly to Spinoza's system. The transition to the Begriffslogik is not an outright rejection or reduction of $<$ substance $>$ to something else, but a redressing of $<$ substance $>$ in logical clothes. The logical relations of conceptuality, on this view, are just better expressions of the metaphysical relation of substance expressed in the Doctrine of Essence. ${ }^{15} \mathrm{On}$ such a view, the theoretically foundational role of the Subjective Logic holds only because the concept (as an "entity") is metaphysically foundational for substance, and for the other "entities" described in the Objective Logic.

I think the continuity view underestimates the "critical function" of Hegel's Objective Logic. ${ }^{16}$ Hegel's account of metaphysical concepts in the Doctrines of Being and Essence does not in general result in a positive view about the nature of reality, simply because his effort is devoted to challenging both the common and sophisticated uses of these metaphysical concepts. The transition to the Doctrine of the Concept is the culminating moment of this critique. This is why Hegel speaks of the "reality that has vanished" (die Realität, welche in ihm verschwunden) in the concept (W 6:263/SL 522). However, in contrast to the continuity view, those who acknowledge the critical side of the Objective Logic often fail to appreciate the sui generis constructive dimension of the Begriffslogik. The Doctrine of the Concept is meant to "rebuild" the reality that disappears in it. ${ }^{17}$ The critique of metaphysics in the Objective Logic is not therewith the end of metaphysics.

The constructive dimension is on display in another set of passages that provide the point of departure for the present interpretation and that have attracted little scholarly comment. In these passages, Hegel seems to be offering a further clue to the nature of the theoretically foundational role of the Doctrine of the Concept:

In their relation to the two preceding spheres of Being and of Essence, the determinate concepts are, as judgments, reproductions [Reproduktionen] of these spheres, but they are posited in the simple relation of the Concept. (W 8:322/EL I $_{7}$ IR $)$

\footnotetext{
${ }^{15}$ Stern, for example, seems to hold such a view. Categories from the Begriffslogik, for him, are "the highest determinations in [Hegel's] philosophical ontology" (Structure, 58). Accordingly, "universality" from the Begriffslogik seems to supersede ontological concepts from the Objective Logic: "Hegel begins his analysis [in the Doctrine of the Concept] with a frankly realist and essentialist account of universality, stating that the universal constitutes the 'essential being' and 'substance of its determinations.' ... Hegel defends the view that it is the universal that constitutes the real nature of the particular individual by claiming that the universal determines what sort of being each individual is; and unless it exemplified a substance-kind the individual could not exist" (Structure, 59). Further metaphysical readings of Hegel's logical vocabulary include McTaggart, Commentary on Hegel's Logic, I90; and Taylor, Hegel, 309, 3 I 3.

${ }^{16} \mathrm{Cf}$. Theunissen, Schein. Other works emphasizing the critical aim of the Objective Logic include Bowman, Absolute Negativity; and Cirullo, Critique of Essence.

${ }^{17}$ The Begriffslogik's reestablishment of categories of "immediacy" is a central feature of Theunissen's argument in Schein. Rüdiger Bubner makes a suggestive allusion to a similar role when he writes, "Now the Begriffslogik, as the Subjective Logic, was nevertheless right from the beginning silhouetted against [abgehoben ... von] the Objective Logic of Being and Essence, and indeed as the concluding establishment of the complete logical consciousness of what was earlier already implicitly exposited" (Zur Sache der Dialektik, I09).
} 
The relationship of forms such as concept, judgment, and syllogism to others like causality, etc., can only establish itself within the Logic itself. (W 8: 8I/EL $24 \mathrm{R}$ )

But all the same, what underlies this classification [Kant's table of judgments] is the genuine intuition that the various types of judgment are determined by the universal forms of the logical Idea itself. Thus we obtain, first of all, three main types of judgment, which correspond to the stages of Being, Essence, and Concept. ... The inner ground of this system of the judgment must be sought in the fact that, since the Concept is the ideal unity of being and essence, the unfolding of it that comes about in the judgment must also, first of all, reproduce [zu reproduzieren] these two stages in a conceptual transformation, while the Concept itself shows itself to be what determines the genuine judgment. (W 8:322/EL $\S_{\mathrm{I}} \mathrm{I} \mathrm{IZ}$ )

These passages make explicit something that, on the one hand, is perfectly obvious to readers of the Logic. Namely, Hegel divides up his discussion of logical forms in the Begriffslogik so that they "correspond" to the three Doctrines. The forms of judgment and syllogism are organized as follows:
Doctrine of Being
A. Judgment of Dasein
Doctrine of Essence
B. Judgment of Reflection
A. Syllogism of Dasein
C. Judgment of Necessity ${ }^{18}$
B. Syllogism of Reflection
C. Syllogism of Necessity
Doctrine of the Concept
D. Judgment of the Concept
$[\text { Objectivity }]^{19}$

Yet the significance of Hegel's organization of the logical forms according to these divisions is not immediately clear. As we will see, Hegel often unhelpfully speaks of a mere "correspondence" between the logical forms and the contents of the Objective Logic. However, in the last and most telling passage quoted above, he speaks of an "inner ground" of the logical forms in the fact that the concept is the "ideal unity" of being and essence. This suggests that he sees an explanatory relation between the Objective and Subjective Logics, and since the latter is given priority, it must bear the explanatory weight. Moreover, he claims that the logical forms "reproduce" the content of the Objective Logic. So even though the Begriffslogik has some explanatory priority to the other Doctrines, the content of the Subjective Logic must largely repeat that of the Objective Logic, something again that is not obvious on its face. And somehow this "reproduction" of the Objective Logic occurs, at least in part, in the account of judgment. This gives us another explanandum.

\subsection{The Kantian Precedent}

The final passage above contains an important reference to Kant's table of judgments, which may provide a clue for Hegel's conception of logical forms. Hegel praises Kant's "genuine intuition" in his determination of the forms of judgment. He also famously endorses a Kantian picture of the relation of logic

18 "Thus we obtain, first of all, three main types of judgment, which correspond to the stages of Being, Essence, and Concept. In accord with the character of Essence, as the stage of difference, the second of these main types is again inwardly divided in two" (W 8:322/EL $\$ \mathrm{I} 7 \mathrm{IZ}$, emphasis added). This explains why there are four judgment types, since B and $\mathrm{C}$ are both assigned to the stage of Essence.

${ }^{19}$ Why is there no "syllogism of the concept"? I contend that when the formal moments of conceptual form are sufficiently unified, there is no reason (other than, say, a methodological one) to distinguish these formal moments. A complete syllogism just gives the structure of an object of a certain sort. See Wolf, "Rethinking Hegel's Conceptual Realism," for an account of this view. 
to metaphysics in a report (Privatgutachten) to his friend Immanuel Niethammer from I 8 I 2, the year the first volume of the Logic was published:

\begin{abstract}
According to my view, metaphysics in any case falls entirely within logic. Here I can cite Kant as my precedent and authority. His critique reduces metaphysics as it has existed until now to a consideration of the understanding and reason. Logic can thus in the Kantian sense be understood so that, beyond the usual content of so-called general logic, what he calls transcendental logic is bound up with it and set out prior to it [vorausgeschickt]. ... [T] hose Kantian distinctions already contain a makeshift or rough version of [my logic]. (W 4:406-7/Hegel: The Letters, 277, emphasis added)
\end{abstract}

Hegel's avowed allegiance to Kant is striking here, though the passage and its surrounding context are not as perspicuous a guide as one might hope. In particular, the passage easily suggests a simple identification of Hegel's "Objective Logic" with Kant's transcendental logic and the "Subjective Logic" with Kant's general logic. ${ }^{20}$ However, if one followed this tempting association strictly, Hegel would be saying the opposite of what he says in the first set of passages quoted in 2.r. There he says that the Doctrine of the Concept provides the foundation for the Doctrines of Being and Essence; but if general logic is associated with the Doctrine of the Concept, he would be saying here that general logic presupposes the Objective Logic: the Objective Logic would be the foundation of the Doctrine of the Concept. Moreover, Kant published nothing like Hegel's Objective Logic. ${ }^{21}$ Hegel could hardly be citing Kant's authority for that precedent. Hence, this simple identification of the two divisions of the Logic with transcendental and general logic respectively is a dead end. As we will see later, Hegel's notion that general logic is "bound up" with transcendental logic calls the very possibility of a general logic into question. A fortiori, the discussion of logical forms in the Begriffslogik is not a general logic at all.

Hegel's specific debt to Kant's reduction of metaphysics to "logic" requires a better explanation. I propose we examine the "genuine intuition" that Hegel mentions in discussing Kant's table of judgments. For Kant, the reduction of metaphysics to a "consideration of the understanding and reason" has its basis in his derivation of the categories of the understanding-his metaphysics of experience-from the forms of judgment. Combined with their connection to the forms of spatiotemporal intuition, the forms of judgment constitute Kant's "transcendental logic," a logic that includes content for cognition. And the pure concepts of metaphysics are derived immediately from transcendental logic. In the Metaphysical Deduction, Kant gives a condensed argument for this derivation:

The same function that gives unity to the different representations in a judgment also gives unity to the mere synthesis of different representations in an intuition, which, expressed generally, is called the pure concept of understanding. The same understanding, therefore, and indeed by means of the very same action through which it brings the logical form of a judgment into concepts by means of the analytical

${ }^{20}$ See Pippin, Shadows, 57. As Michael Wolff points out ("Science of Logic," 74-75), Hegel says the Objective Logic "would" overlap "in part" with Kant's transcendental logic. The identification should not be made too simply.

${ }^{21}$ Kant's lectures on metaphysics, of course, occasionally resemble Hegel's Logic thematically, since they follow the structure of Alexander Baumgarten's Metaphysics. These lectures were not available to Hegel, however, and he has in mind a general feature of Kant's view and not an isolated text. 
unity, also brings a transcendental content into its representations by means of the synthetic unity of the manifold in intuition in general, on account of which they are called pure concepts of the understanding that pertain to objects a priori.... In such a way there arise exactly as many pure concepts of the understanding, which apply to objects of intuition in general a priori, as there were logical functions of all possible judgments in the previous table. (A 79/B I05) ${ }^{22}$

The details of Kant's argument need not concern us. What matters for us here is his conclusion that pure concepts can be derived from "logical functions." As a result of the association of pure concepts of metaphysics with the table of judgments and forms of intuition, Kant can sometimes speak as if transcendental logic replaces ontology, the domain of "general metaphysics." He writes in "Phenomena and Noumena,"

The Transcendental Analytic accordingly has this important result: That the understanding can never accomplish a priori anything more than to anticipate the form of a possible experience in general, and, since that which is not appearance cannot be an object of experience, it can never overstep the limits of sensibility, within which alone objects are given to us. Its principles are merely principles of the exposition of appearances, and the proud name of an ontology, which presumes to offer synthetic a priori cognitions of things in general in a systematic doctrine (e.g. the principle of causality), must give way to the modest one of a mere analytic of the pure understanding. (A 246-47/B 303)

There is a clear sense in which Kant's transcendental logic renounces traditional ontology altogether. Ontology is a consideration of the basic predicates of entia or "things in general." ${ }^{3} 3$ This project requires "being" to function as a count-noun with certain universally shared properties. Kantian transcendental logic does not provide an ontology in this sense at all, since it restricts our attention to "objects of experience," abandoning any a priori principles for objects outside that domain (whatever they may be). Kant thereby undermines the absolute generality of the scope of traditional ontology. ${ }^{24}$ On the other hand, Kant also shows how the a priori concepts of ontology have a genuine use. In this sense, he preserves metaphysical concepts by showing their legitimate origin in the principles of the understanding, namely, in transcendental logic.

In his preservation of a role for metaphysical concepts, Kant offers a first approximation of the supervenience thesis I will attribute to Hegel. In Kant's case, metaphysical concepts supervene on the forms of judgment in transcendental logic. The core idea of "supervenience" concerns the covariance of one level of

${ }^{22}$ References to the Critique of Pure Reason use the standard A/B pagination. References to Kant's other works are to the volume and pagination of Kants gesammelte Schriften. These page numbers are found in the margins of the respective English translations cited in the bibliography.

${ }^{23} \mathrm{Cf}$. Meier: "We see therefore from what we have learned that ontology puts us in a position to know something about all possible things; and thus up to now ontology has been a science of all possible things without exception" (Metaphysik, §ıо2).

${ }^{24} \mathrm{Kant}$ is of course free to say that he does have an ontology, so long as the change from the traditional concept is thoroughly clarified. See Kant, Metaphysik Mrongovius, 29:784. But see: "thus the science of all basic concepts and basic propositions upon which all of our pure cognitions of reason rest is ontology. But this science will not be properly called ontology. For to have a thing in general as an object is as much as to have no object and to treat only of a cognition, as in logic" (Metaphysik Mrongovius, 29:786). 
a thing with something of another level: roughly, $\psi$-things supervene on $\phi$-things if any variance in the $\psi$-way-things-are depends on a coordinate variance in the $\phi$-way-things-are (where $\phi$ and $\psi$ are not intensionally identical). ${ }^{25}$ According to a common application of the term, the mind-way-things-are supervenes on the brain-way-things-are. ${ }^{26}$ This is a one-directional relation of dependency, and it is thus different from identity in a standard sense. The brain-way is not the same as the mind-way. They have different properties. All the same, the brain-properties "fix" what mind-properties there may be. There cannot be a change in the mind without a coordinate change in the brain. ${ }^{27}$

In Kant's view, metaphysical concepts are one-directionally dependent on forms of judgment in transcendental logic in a similar way. To have the table of categories, all you need is the table of judgments along with the forms of intuition-not vice versa. Moreover, the dependence of the categories on transcendental logic is exhaustive. To understand $<$ substance $>$, you must understand the role of the subjectterm in judgments of experience, with their necessary temporal determinations. ${ }^{28}$ To understand <accident $>$, you must understand the predicate-term in the same type of judgment. The "natures" of substancehood and accidenthood contain nothing beyond the judgmental role on which they supervene. The forms of judgments "fix the facts" about these categories. Further metaphysical speculation would simply miss the point. ${ }^{29}$

The supervenience thesis gives Kant a procedure for grounding every legitimate metaphysical concept. Each must be shown to depend on a principle whose basis lies in a form of judgment in transcendental logic. Hegel's specific reference to Kant's table of judgments, and the "genuine intuition" contained therein, gives us reason to expect Kant's influence on this point. Moreover, the precedent of Kant's supervenience thesis can explain the theoretical priority of the Doctrine of the Concept suggested in 2.I. While it is common to suppose that Hegel's metaphysics is Kantian in spirit, the supervenience thesis demands that metaphysical concepts also be tied to the "letter" of transcendental logic. If Hegel follows Kant on this score, his metaphysical concepts must be more closely tied to logical forms-not simply "thought" or "thinking" - than is usually appreciated. I will try to show that Hegel does follow Kant on this point, though with a crucially different conception of "transcendental logic." It is through a fine-grained connection of metaphysical

${ }^{25}$ See McLaughlin and Bennett, "Supervenience," for a useful summary. By excluding cases of intensional identity, I only mean to set aside cases where covariance would be trivial.

${ }^{26} \mathrm{Cf}$. Kim, Mind in a Physical World, 5-I 5 .

${ }^{27}$ Thanks to Josh Mund for suggesting important corrections to this paragraph.

${ }^{28} \mathrm{E}$.g. "Likewise the proposition 'Nothing comes from nothing' is only another consequence of the principle of persistence, or rather of the everlasting existence of the proper subject in the appearances. For if that in the appearance which one would call substance is to be the proper substratum of all time-determination, then all existence in the past as well as in future time must be able to be determined in it and it alone" (A I 85/B 228, emphasis added). See B 304 for the necessity of intuition for the introduction of the logical relation of subsumption, crucial for the asymmetry of the categories of substance and accident.

${ }^{29}$ This is very near to Brandom's claim that metaphysical concepts are "sense-dependent" on subjective pragmatic categories. See his Spirit, 208-IO. However, I am not yet convinced that the sense-dependence is "reciprocal." Thanks to an anonymous reviewer for recalling my proximity to Brandom's view here. 
concepts to these logical forms, I will argue, that we should understand Hegel's general claims about the priority of the Subjective to the Objective Logic.

\section{HEGEL'S REPUDIATION OF GENERAL L OGIC}

To understand Hegel's explanation of metaphysical concepts, his challenge to general logic must first be understood. I have already mentioned in passing that Hegel offers no general logic and even challenges the whole notion. Once we have a reasonably clear conception of general logic, the reason for this is not so obscure as may be thought. Hegel's challenge to general logic does not stem, for example, from an adherence to an alternative dialectical or dialethic logic. Instead, Hegel abandons the notion that logic can be represented without distinguishing between “conceptual types." Here I follow Michael Wolff's reconstruction of general logic as it was common to the syllogistic or term logic accepted by Aristotle and Kant, despite their differences. ${ }^{\circ}$ The mark of general logic, according to Wolff, is that its logical forms contain no terms other than concept words, and concept words (unlike proper names, for example) can be used indifferently in the subject and predicate place. ${ }^{3 \mathrm{I}}$ Syllogistic forms require that terms play a neutral conceptual role so that, for example, a middle term can be used first as a predicate but then as a subject. A purely general logic would contain only one unmarked variable type, corresponding to concept words.

According to this conception of general logic, Wolff argues, Aristotelian and Kantian syllogistic is general or formal, while Fregean (now "classical") and other forms of mathematical logic are not. The Fregean comparison may help this notion of general logic become clearer. Frege's innovation, followed by all subsequent "mathematical logic," was precisely to introduce a distinction between terms that represent objects - proper names or individual variables - and those that represent concepts-functions or predicates. ${ }^{32}$ This required at least a two-type system of terms in a function-argument structure, namely, $\mathrm{Fa}$. At its most basic, this structure demands that proper names represent singular objects and predicates general functions that can take many arguments. Such a structure is necessary for complex logical quantification. ${ }^{33}$ Despite its many advantages for the construction of a mathematical logic, Wolff argues that Frege's innovation introduces nonlogical distinctions that preclude it from being general in the Kantian sense.

${ }^{30}$ See Michael Wolff, Abhandlung, $\$ 36$.

${ }_{31}$ "Syllogistic is formal and thus pure logic exactly in the sense that, as such, it neither makes use of conceptual constants nor takes into consideration other interpretations for concept variables (so that totally disregards the content of concepts). It therefore makes use neither of individual variables nor of individual constants and hence prescinds from everything intuitive and non-conceptual, consequently from all relations of concepts to objects" (Michael Wolff, Abhandlung, \$36). 'Concept word' is a Fregean term, used to contrast with proper names. Unlike proper names, concept words are connected "with the indefinite article, with words like 'all', 'some', 'many', etc." (Frege, Wissenschaftlicher Briefwechsel, I 50). See also Frege, Frege Reader, I 49-50.

${ }^{32}$ See especially Frege, "On Concept and Object," in Frege Reader, I8 I-93.

${ }^{33}$ See Dummett, Frege: Philosophy of Language, chap. 2, for a rich appreciation of Fregean logical structure vis-à-vis the power of quantification. 
Frege's logic is thus a "transcendental" one, if that means that some cognitive distinction is made with respect to the variables appearing in its axioms. ${ }^{34}$ As Wolff shows, Fregean logic must assume a nonlogical distinction between the terms occupying the respective roles of function and argument. Though this may amount to a critique of Frege on Frege's own terms, it is only as damaging as the aspiration to a general logic is a good one. Hegel thinks it is not. Without assimilating Hegel's view to Frege's, we can see that Hegel lacks a purely general logic for similar reasons; yet unlike Frege, he repudiates it deliberately. He also does so by insisting on the importance of conceptual "types" in the representation of logical forms. ${ }^{35}$ The result is his affirmation of what he calls "logical content." Our tendency to take for granted a postsyllogistic conception of logical form may have prevented contemporaries from noticing Hegel's pre-Fregean innovation, not to mention its connection to his critique of metaphysics. ${ }^{36}$

What I call conceptual "types" are roughly what Hegel calls the "moments" of the concept: universality, particularity, and singularity. ${ }^{37}$ These basic structural elements of the concept are derived at the end of the Objective Logic (W 6:240/ $S L$ 505). Though this is a controversial transition in the Logic, we can ignore its justification for present purposes and treat $<$ universality $>$, $<$ particularity $>$, and <singularity $>$ as the new "primitives" of the Doctrine of the Concept. Hegel sometimes discusses "the concept" in the singular, and he claims that all three moments are fully identical in "the concept" thus designated. Stated simply: the structure of conceptuality as such can be seen equally as one of universality (a whole "conceptual space"), its constitutive particular concepts, or as a structure of singular objects represented by the concept..$^{38}$ This unified dimension of these moments need not (mercifully) detain us here, however. What is important for now is the way these integral moments of the concept as such fall apart in a judgment: "The immanently reflected determinations [i.e. universality, particularity, singularity] are determinate totalities that are just as much in an essentially disconnected subsistence, indifferent to each other, as they are through mediation with each other" (W 6:302/SL 550, translation modified). The judgment represents the moments of conceptuality as nonidentical. The judgment "has not yet restored itself to the unity through which it exists as concept" (W 6:306/SL 552). In other words, though Hegel contends that conceptuality as such "dissolves" the distinction

${ }^{34}$ As far as I know, Michael Wolff does not call Frege's logic "transcendental," but he claims that Fregean "arguments" correspond to Kantian intuitions, even if not spatiotemporal intuitions; see Abhandlung, $\$ 36$.

${ }^{35}$ Bertrand Russell later attempted to produce a more differentiated type-logic in order to avoid self-referential contradictions in "Theory of Types" ( I908).

${ }^{36}$ Redding, "Role," 287-90, appreciates Hegel's use of conceptual determinations to replace the formalism of the Aristotelian syllogistic, though not (I believe) the connection to Hegel's critique of metaphysics that I will detail below.

${ }^{37}$ Singularity does not represent a kind of concept, however. My use of 'type' is untechnical, so I will ignore this complication for now.

38"It follows that each of the determinations established in the preceding exposition of the concept [i.e. the moments] has immediately dissolved itself and has lost itself in its other. Each distinction is confounded in the course of the very reflection that should isolate it and hold it fixed" (W 6:298-99/SL 548 , emphasis added). On this dimension of "the concept" as the whole of "logical space," see Koch, Evolution des logischen Raumes, I49-60. 
between universal, particular, and singular, these distinctions reappear in the form of judgment.

Immediately after the quotation just provided, Hegel gives us a taste of what he means: "As contrasted to the predicate, the subject can at first be taken, therefore, as the singular over against the universal, or also as the particular over against the universal, or the singular over against the particular" (W 6:302/SL 55 I). Hegel claims here that the two terms involved in a basic judgment can take on the significance (respectively) of universal, particular, or singular. In the first instance, for Hegel, the judgment represents a singular subject that is characterized by a universal predicate. Evidently, in such a judgment the subject and predicate, the singular and universal, are not identical. Unlike the concept as such, therefore, the judgment in this form expresses a "contradiction" between subject and predicate, singular and universal (see W 6:3 I0/SL 556).39

Hegel eventually classifies forms of judgment according to how they involve singular, particular, and universal terms. His project is not mere classification, for he thinks from these primitives he can derive the forms of judgment and syllogism, unlike his predecessors who, he complains, listed these forms haphazardly. Though Hegel's derivation is significant, I will not attempt to follow it here, only the principle on which the distinction between the forms rests. As Georg Sans has noted, as a way of classifying judgments, Hegel's approach is novel..$^{\circ}$ In traditional syllogistic logic, universal, particular, and singular qualify whole judgments, rather than first distinguishing the concepts variously involved in a judgment. Kant, for example, thinks of all concepts as general or universal in form, and thus the combination of concepts in a judgment does not involve a difference in the type of terms. ${ }^{4 \mathrm{I}}$ This is what qualifies his logic, according to Wolff's account just described, as general. While some have suggested that Kant's conception of intuition also prefigured Fregean logic, ${ }^{42}$ this prefiguration falls squarely within transcendental logic. Indeed, Kant explicitly states that in terms of general logic, singular terms must be treated as if they were general (A $7 \mathrm{I} / \mathrm{B} 98$ ).

By contrast, Hegel elevates the importance of type-distinctions in logical form such that a general logic that ignored these types is altogether disqualified. ${ }^{43}$

${ }^{39}$ Apparently, Hegel believes that the "true" form of judgment would express the identity between the subject and predicate. Judgments including an asymmetry between singular and universal evidently do not express identity. Therefore, they are formally untrue or contradictory. See W 6:309-IO/SL 556. This feature of Hegel's view shows the grain of truth in Russell's charge that Hegel confused predication with identity (something, it seems to me, that could certainly be charged of Fichte, who took the form of judgment to be $A=B$ ). The truth in the charge is that Hegel thought judgments should express identity (to "restore again this identity of the concept" [W 6:309-10/SL 556]); it is unfair, though, given his view that most forms of judgment fail to express this identity, which shows that he clearly did not confuse the two notions. See e.g. Stern, Hegelian Metaphysics, chap. 2; and Rosen, Idea, 250.

${ }^{40}$ Sans, Realisierung, I IO-I I.

${ }^{41}$ Kant, Jäsche Logic, 9:99, takes universal and particular to mark a difference in use. However, in context this seems to mean that this is not an intrinsic feature of concepts, but connected only to their relations. Primarily, these terms are the quantities of judgment. See Jäsche Logic, 9: IO2; and A 70/B 95.

${ }^{42}$ See e.g. Hintikka, Kantian Themes.

${ }^{43}$ This statement should be qualified. It is not that Hegel denies that a general logic could be constructed symbolically. He was well aware of attempts at formalizing mathematical logic in his day, including those of his own teacher Gottfried Ploucquet (see Redding, "Role," 292), though these attempts may not qualify as general by Michael Wolff's criteria either. However, Hegel seems to believe 
When he determines the possible forms of judgment (using the moments as primitives), he claims that each has distinct "logical content." He writes, "Since logic is the science of the absolute form, this formal discipline, in order to be true, must have a content in it which is adequate to its form" (W 6:267/SL 524). The logical content is just the role that the "moments" play in a given judgment or syllogism. Though Hegel does not offer a thorough discussion of logical content, I think the notion just outlined can be recovered from his remarks. ${ }^{44}$ For, on the one hand, he distinguishes logical content sharply from the "material" of a judgment. The material of a judgment would be the specific content that would fill the place of variables. For example, "rooster" and "crows" are the material of the judgment "The rooster crows." Hegel rightly says such "material [Materie] is no concern in logic" (W 6:388/SL 6I 5). On the other hand, logical content is more than the completely empty syntax of general term logic, for this would provide no means of distinguishing one judgment from any other. (As I have just claimed, the generality of syllogistic logic lies in its lack of such distinction.) Instead, the logical content of a judgment is the implicit role of its terms vis-à-vis the formal moments of universality, particularity, and singularity: "These are the determinations [i.e. singular and universal] that constitute the truly logical content" (W 6:3 I 6/SL 562). If we take the example just given, "The rooster crows," we can ascribe two distinct logical contents to it. On one reading, it contains a singular term characterized by a universal predicate. It is this reading that could be expressed if it was used observationally. 45 This reading would conform roughly to the example Hegel himself gives when he introduces the notion of logical content, namely, "the individual is a universal" (W 6:268/SL 525). On another reading, however, it would function not as an observation but a characterization of roosters in general. Here, "the rooster" would be treated as a generic. The logical content would be that of a universal term characterized by a universal predicate. This example shows how the same linguistic item can function to express two distinct logical contents. ${ }^{4}{ }^{6}$

Given the need to disambiguate logical content in this way, it is arguable that one cannot understand the propositional content of sentences like the one just given unless one implicitly understands how the terms are functioning with respect to their logical content. Logical content is not imposed on sentences from the outside; it is necessary for sentences to make sense at all. Moreover, it is not reducible to mere "form" if that is to mean the bare syllogistic or term-logical

that no general logic can adequately represent the differentiated logico-syntactic structure involved in basic human thought, which he thinks cannot be ignored in the representation of logical form. See, for example, Hegel's challenge to attempts to leave out natural language in the representation of logic: W 6:294-95/SL 545-56.

${ }^{44}$ Below is a more specific and direct account of logical content for Hegel than I have found in the literature. See the brief remarks of Pippin, Shadows, 85, which do not mention the role of the "moments" in logical content.

${ }^{45}$ Redding seems to see the perceptual context as determining the form of judgment: "To sum up: in the context of acts of perception, a judgement will be thought of as having a logical form in which a trope-like singularized universal inheres in a subject treated as an instance of a kind" ("Role," 292). I think we should see things the other way around. Judgments of perception are possible because of a certain logical content that allows us to distinguish singulars from universals in the right way.

${ }^{46}$ Here I am in agreement with Redding, "Role," 288. 
form: $A$ is $B .{ }^{47} \mathrm{Hegel}$ insists on this explicitly: "This expression [i.e. 'the singular is universal'] must not be put in the form of 'A is B,' for A and B are totally formless and hence meaningless names, whereas judgment in general . . . has determinations of the concept for its extremes" (W 6:3 I $2 / S L 558$ )..$^{8}$ If no typedistinction is introduced in logical form between singulars and universals, then the two readings of the sentence above cannot be distinguished, nor could their respective logical consequences; yet in terms of the basic subject-predicate syntax of term logic, they are the same. ${ }^{49}$ For this reason, no judgment can be adequately represented with merely empty variable forms, and "abstraction cannot be made from" logical content (W 6:388/SL 6I 5).

Since the formal moments are Hegel's only "building blocks" for the forms of judgment, ${ }^{5 \circ}$ every judgment must be explained as having logical content in some way: every form of judgment should be in some way an iteration, combination, and/or qualification of the formal moments of universal, particular, and singular, in the roles of subject and predicate. ${ }^{5 I}$ This much seems to be the basis of Hegel's determination and differentiation of logical forms proper. Yet this insistence on the ubiquity of logical content amounts to a repudiation of purely formal, general, type-neutral logic; for general logic assumes that abstraction can be made from such logical content. ${ }^{52}$

\section{THE S U PER VEN I ENCE OF META PHYS I G L C O N G EPTS ON LOGIGA L CON T E T T}

Though not fully developed, Hegel's notion of logical content, as we have seen, suggests an interesting departure from the Kantian conception of transcendental

${ }^{47} \mathrm{Hegel}$ shows that he has a similar conception of logical form as Michael Wolff's view of syllogistic logic. Hegel writes, "Nothing else is reckoned as the form of judgment except that the latter is a connection of two concepts. But we have seen that these two concepts are not just the relationless determination of a sum, but that they relate to each other as singular and universal" (W 6:3 I7/SL 562). Michael Wolff claims likewise that the basic form of syllogistic sentences, categorical form, "represents a relationship between exactly two concepts which can be presented by logical constants such as, e.g. 'every . . is a . . .' and to that extent possesses logical simplicity" (Abhandlung, §5).

${ }^{48}$ The immediate context of this quotation is a discussion of syllogistic form, but the same applies mutatis mutandis to judgment.

${ }^{49}$ Thus does Hegel object to the definition of judgment as the "combination of two concepts" as it was defined by Christian Wolff (see Vernünftige Gedanken, I 56-57); for "this definition of judgment ignores what is essential to [the judgment], namely the difference of its determinations" (W 6:306/ $S L$ 553). I take "determinations" here to be a reference to the formal moments.

${ }^{5} \mathrm{Hegel}$ also makes heavy use of the terms "abstract" and "concrete" to further qualify the moments, i.e. "abstract singular" or "concrete universal." These terms do not receive an independent justification in either the Objective or Subjective Logic. I will not question their legitimacy in this context, but they certainly allow Hegel to produce further cases of logical content than would be possible from the mere concatenation of the three primitives.

${ }^{51}$ Redding's formulation here seems apt: "Hegel notes that 'every judgment is in principle also an abstract judgment' ... the implication seeming to be that in making a judgment of determinate being such as 'the rose is red' one simultaneously commits oneself to a higher-order judgment concerning the categories exemplified by the terms in the initial judgment. Thus to assert that 'the rose is red' is to implicitly assert the abstract proposition 'the singular is universal' - an identity that is rooted in the ultimate unity of the 'moments' of conceptuality-universality, particularity and singularity" ("Subjective Logic," I79-80).

${ }_{52}^{2}$ I think it is preferable to say that Hegel repudiates general logic, rather than saying that he thinks a "strict distinction between general and transcendental logic [is] impossible" (Pippin, Shadows, I04). However, this is somewhat a matter of how terms are fixed. 
logic and thus metaphysics. Convinced that general logic is empty of content, Kant concludes that metaphysical concepts can adhere to the forms of judgment only after adding something else: the forms of intuition. But Hegel does not accept any empty conception of logic. In order to represent thought at all, logic must at least distinguish the conceptual moments that constitute every judgment. Accordingly, to Hegel the problem of deriving content from the logical forms does not seem intractable from the outset. Nor do the forms of intuition play any significant role in Hegel's replacement for transcendental logic..$^{53}$

It is the aim of this section to provide a model, in the form of a general argument, of Hegel's conception of the relation of metaphysical concepts to logical forms or logical content. Hegel nowhere works out systematically the model I will offer, though many texts point in its direction. I will restrict my attention here to Hegel's discussion of judgments, which should suffice for a more precise conception of the relation of logic and metaphysics to emerge. What I say about judgments should apply, with some important adjustments, to the other logical forms as well: the moments of conceptuality themselves as well as the forms of syllogism. The model, if correct, would encourage a general, and I hope fruitful, interpretive program for Hegel's Logic. Needless to say, that program cannot be carried out here.

The previous section has authorized us to assert the following premise on Hegel's behalf:

(I) All forms of judgment have logical content.

We can now see that this is not a trivial premise, since, as Hegel understands logical content, traditional syllogistic logic denies (I), or at least ignores its relevance. It is Hegel's belief in (I) that leads him to repudiate general logic. However, he does not so much argue for this premise as demonstrate it by constructing an exhaustive series of logical forms using his primitives. We will see some examples of this in what follows. By showing that the distinction between types of judgment relies on different respective logical contents, he shows that the "moments" are necessary for distinguishing forms of judgment. If so, then a formal account that elides distinctions of logical content is insufficient.

Now I will attempt to show that in his discussion of the logical forms, the following two premises lie in the background of Hegel's account:

(2) All logical content has an "objective meaning."

(3) Metaphysical concepts supervene on the "objective meaning" of judgments.

These will lead to our desired conclusion:

(4) Metaphysical concepts supervene on the forms of judgment.

${ }^{53}$ For this reason, I still find curious Pippin's continuing attempt to appeal to the inseparability of concept and intuition to explain Hegel's conception of logic and metaphysics vis-à-vis Kant. See Pippin, Hegel's Idealism; Shadows, 82. The notion of logical content helps us avoid a reference to intuition, even inseparably combined with concepts, in the explanation of Hegel's metaphysics. Whether logical content explains the applicability of logic to the world is a deeper issue, here unsolved. 
(2) is strictly textual and relies on a quasi-technical use of language. Hegel sometimes, though not always, says that a judgment of a certain form has an "objective meaning" or "significance" (objective Bedeutung) (e.g. W 6:307/SL 554; W 6:322/SL 566; W 6:356/SL 59I). Since nothing special seems to distinguish the cases where he mentions the objective meaning, I think we can assume it holds in every form of judgment. The question is what this "objective meaning" is. (3) is my attempt to elucidate the intended consequences of Hegel's use of the term, and it is the focus of my exposition.

Hegel's most explicit account of the objective meaning of judgments begins with this description of the most immediate logical content, "the singular is universal." He says of this form:

In this way, the start is made from the singular as the first, the immediate, and through the judgment this singular is raised to universality, just as, conversely, the universal that is only in itself descends into existence [Dasein] in the singular or becomes a being that is for itself [Fürsichseiendes]. (W 6:307/SL 554, translation modified)

He then uses "objective meaning" to refer to this phenomenon:

This significance of the judgment is to be taken as its objective meaning and at the same time as the true significance of the previous forms of transition. What is becomes and changes, the finite perishes in the infinite; the existing emerges from its ground in the appearance and collapses; the accidents manifest the wealth of substance as well as its power. ... Now this transition [i.e. from the Doctrine of Being] and showing [i.e. from Essence] has passed into the original dividing of the concept, and this division, in bringing the singular back to the in-itselfness of its universality, equally determines the universal as something actual. ... But equally pertaining to this objective meaning is that the said distinctions ... emerge again [wieder hervortreten] in the determinateness of the concept. (W 6:307/SL 554, translation modified)

There is much here that exceeds the scope of my present exposition. What is evident is that the objective meaning of a judgment pertains to concepts belonging to the Objective Logic, and in particular to the relations between concepts in those spheres. In the Doctrine of Being, concepts undergo "transition" (übergehen); in the Doctrine of Essence, they "show" (scheinen) themselves in one another. Hegel says that the objective meaning of the judgment, in which one term relates to another, is the "truth" of these relations. This implies for him that the previous conceptual distinctions "emerge again" in the Doctrine of the Concept, now in their true form. The objective meaning of the judgment (and other logical forms) is thus the way in which these previous conceptual relations reoccur. The paucity of explicit references to the objective meaning should not diminish our expectation of its importance.

Still, the above passage does not much explain the content of the objective meaning of judgments. It should be useful to consider Hegel's further analysis of the same basic judgment type:

The objective meaning of the proposition stating that the singular is universal conveys ... both the perishability of singular things and their positive subsistence in the concept in general. The concept is imperishable, but that which emerges from it in its division is subjected to alteration and to falling back into its universal nature. But the universal, conversely, gives itself a determinate existence. (W 6:3 I3/SL 559, translation modified) 
This passage claims that a singular judgment in its most basic form, what Hegel calls a "positive judgment," expresses an objective meaning, and that this objective meaning pertains to both terms involved in the judgment. The objective meaning of the positive judgment pertains, moreover, to the logical content specific to it. In this case, the subject term is a singular, and this use of a singular term implies "perishability" (Vergänglichkeit). The predicate is a universal term, and this term subsists outside of the singular while also attaining determinate existence (Dasein) in the singular.

In both elements of the logical content, some "objective" concept is attached: $<$ perishability $>$ and <existence $>$. Though Hegel's use of "perishability" may suggest a kind of natural process, it is for Hegel first and foremost a defining feature of finite things, entities in the category of "existence" (Dasein) from the Doctrine of Being; it stems from the disunity in these things between object and concept. ${ }^{54}$ Yet here, Hegel sees <perishability $>$ expressed in the asymmetry between subject and predicate in positive judgments. I think we can make sense of this. The singular term has, in these judgments, a potentially momentary usage. Most clearly, the referent of the 'this' changes as the sentence is repeated (a point Hegel demonstrates in the Phenomenology as well). Hegel's example at this point in the Logic, "The rose is red," is evidently meant to be taken referentially, as picking out a singular rose. Here, too, the referent of 'the rose' can change with the context, and the predicates ascribed to it at one time may not apply at another. In this way, it "perishes." The predicate, meanwhile, can be used to characterize a number of such singular items. It thus has "positive subsistence" (ihr positives Bestehen) even if it depends on the singulars to achieve "concrete existence." Simply put, it lasts outside the context and applies to new objects even when the first disappears. Taken together, this logical content expresses a relation between two kinds of objective "being": a momentary singular existence (expressed by the singular term), and an abiding universal subsistence (expressed by the predicate). These objective categories stem not from additional theories attached to the use of terms in judgment, but from the logical content of the judgment itself. Moreover, the "objective" concepts (like < Vergänglichkeit $>$ ) expressed in this form of judgment do not adhere to any use of singular terms (for example), but to singular terms conjoined to predicates in a referential use of the positive judgment. The objective meaning differs on the basis of the logical content of the whole judgment, not simply the terms.

From this case, we learn that the objective meaning involves the connection of metaphysical vocabulary from the Objective Logic to the logical content of forms of judgment. However, what is the nature of this connection, or "correspondence," as Hegel sometimes vaguely says? More strongly than mere correspondence, Hegel believes, I think, that the concepts of the Objective Logic, which appear again in the objective meaning of judgments, supervene on the objective meaning, that is itself implicit in logical content of judgments. This supervenience implies an "existential"

${ }^{54}$ As discussed in the Doctrine of Being: "It is the definition of finite things that in them concept and being are different; that the concept and reality, soul and body, are separable; that they are therefore perishable [vergänglich] and mortal" (W 5:92/SL 66). See also W 5:I42/SL IO3. The root concept $<$ Vergehen $>$ is a feature of $<$ becoming $>$ as such. See W 5:I I I-I 2/SL 80. 
dependence of the objective concepts on the logical content. That is, there would be no such concepts of the Objective Logic apart from the distinct forms of logical content, and the specific concepts there are depend on the differences of logical forms. If this sounds implausible, first recall the clear evidence presented above (2.I) that, though the Objective Logic linearly precedes the Subjective, Hegel says in a number of places that the Objective Logic has the Subjective Logic as its foundation. There may be many reasons why the Objective Logic should precede the Subjective in the order of exposition, but Hegel is quite clear about the order of explanation. My claim at present is that this order of explanation can be seen not only in the broad outline of the Logic, but at the fine-grained level of logical forms, such as the one we have just seen. Hegel's view that the Objective Logic rests on the Subjective Logic should be cashed out in terms of the supervenience of metaphysical concepts on logical content. Unlike Kant, Hegel does not connect this supervenience to the addition of the forms of intuition, since he thinks that logical content itself is rich enough to imply an "objective meaning." The variety of logical contents in the Subjective Logic explains the variety of ontological concepts available in the Objective Logic.

Some other interpretations refer to the correspondence between ontological concepts and logical forms, but without explaining the order of dependence. Discussing the form of judgment connected to the substance/accident distinction, Paul Redding writes, "Retaining Hegel's way of portraying the situation, however, the logical relation of predication can be seen as mirroring the ontological relation between a property and a substance: one thinks of the intension of the predicate as $i n$ that of the subject just as the rose's redness is in the rose itself." ${ }_{55}$ Redding is one of the few commentators who take the discussion of logical forms seriously. But it is unclear from his account which way the order of explanation between ontological and logical relations should go: "mirroring" here is noncommittal on the issue. Do we use certain logical forms because of our independent ontological views, or do ontological concepts, including those articulated in Hegel's Objective Logic, depend on certain logical forms? My concern with Redding's formulation is that it allows that something like predication could depend on an independent ontological view. ${ }^{56}$

On the present account, there is a clear direction to the explanatory dependence. The concepts of a substance/accident metaphysics, for example, do not stand independently from a certain form of judgment, but result from the supervenience of those metaphysical concepts on that form of judgment. Hegel goes on to explain:

The subject, the immediate singular at first, is in the judgment itself referred to its other, namely the universal; it is thereby [somit] posited as the concrete-according to the category of being, as a something of many qualities; or as the concrete of reflection,

${ }_{55}^{5}$ Redding, "Subjective Logic," I 8I.

${ }^{56}$ Though Redding would surely acknowledge that the ontological view would be a false one, as Hegel frequently suggests that substance/accident metaphysics is absurd. In the nearby context, he writes, "The subject without the predicate is what the thing without properties, the thing-in-itself, is in the sphere of appearance, an empty indeterminate ground" (W 6:307/SL 554). Similar themes are developed in the Phenomenology's "Perception: The Thing and Illusion," W 3:93-I36/ PS III I I I-65. 
a thing of manifold properties, an actual of manifold possibilities, a substance of precisely such accidents. (W 6:3 I3-I4/SL 559)

Though the metaphysical concepts mentioned in this passage are discussed earlier in the Objective Logic, they are now explained as adhering to the role of the subject in the positive judgment. ${ }^{57}$ Those concepts supervene on this logical content. (Though not conclusively, the "thereby" [ somit] here may speak in favor of the order of dependence I am advocating.) It would be psychologically inaccurate to say that predication implies the belief in substance and accidents. I prefer to say that the concepts $<$ substance $>$ and $<$ accident $>$ supervene on this form of judgment. This allows that the ontological concepts depend on the forms of judgment but does not imply that the development of these concepts is an inevitability, as it would be if the belief already followed. Historically, it often took great thinkers like Plato and Aristotle to articulate ontological beliefs, even though logical contents were long in currency. Moreover, on my view, it is quite significant that metaphysical concepts, rather than truths, supervene on logical forms. Hegel is not using the notion of logical content to justify metaphysical claims or principles. Indeed, it was precisely the error of earlier metaphysicians to use formal logical principles as a sure guide to ontology.$^{58}$ By contrast, in general, Hegel thinks the form of judgments is "untrue." So an explanation of how metaphysical concepts supervene may be used to diagnose how metaphysical "untruths" arise. Since Hegel's account of metaphysical concepts in the Objective Logic is often critical, this is a welcome result. The Objective Logic shows how metaphysical concepts, once extant, are often intrinsically inadequate or dialectical. The Subjective Logic shows how the inadequacy can be explained through their supervenience on "false" logical forms. ${ }^{59}$

Thus, instead of allowing that metaphysical concepts are formed from an independent view of the world and merely correlated with forms of judgment, I wish to frame Hegel's view quite differently. If the Begriffslogik is the foundation of the Doctrines of Being and Essence, then we should construe the form of judgment

${ }^{57}$ See again Brandom, Spirit, 208-10.

${ }^{58}$ This is what Baumgarten does with the principle of excluded middle, for example, since he interprets it first in terms of entia: "Every possible thing is either A, or not-A, or neither (§8). Now, what is neither is nothing, because it would be both of these (\$9). Therefore, every possible thing is either $A$, or not-A, or, for every subject, one out of each pair of contradictory predicates is suitable. This proposition is called the principle of the excluded third or middle between two contradictories" (Metaphysics, §IO).

${ }^{59}$ One of the most thorough accounts of Hegel's critique of the form of judgment in metaphysics comes from Chong-Fuk Lau (Urteilskritik, "Categories"). Lau interprets the problem in terms of the "ontological assumptions" of the form of judgment: "The underlying concern of Hegel's critical examination is directed toward the ontological assumptions that come with the form of judgment. It attacks the ontological dichotomy of substance and accidents resulting from hypostatizing the logical subject-predicate asymmetry" ("Categories," 96). However, Lau sees Hegel's critique of substanceaccident metaphysics as rooted in an alternative "subjectivity-ontological monism" (Urteilskritik, I94). Though I have not been able to elaborate on Hegel's positive use of metaphysical concepts here, appeal could be made to the form of the syllogism, which leads to an adequate use for metaphysical concepts. Syllogisms can express the "nature" of things: "The nature of something [ der Sache] is that its distinct conceptual determinations are unified in essential unity" (W 6:358/SL 593, translation modified). Given the proper role of the syllogism in supporting metaphysical concepts, I do not believe we need to point to a monistic ontology to explain Hegel's critique of the judgment. However, I cannot make the case here. 
as the foundation of metaphysical concepts like < substance $>$ and <accident $>$. This is because different forms of judgment each have different logical content; and logical content includes some form of "objective meaning." These objective concepts depend on logical content, and not vice versa. Metaphysical concepts supervene on logical content in that the full variety of metaphysical content stems from the diverse role of terms in judgments. ${ }^{60}$

In case one is skeptical that Hegel could hold such a view, it is worth recalling his words from the I83 I Preface to The Science of Logic. He writes,

The forms of thought are first set out and stored in human language, and one can hardly be reminded often enough nowadays that thought is what differentiates the human being from the beast. In everything that the human being has interiorized, in everything that in some way or other has become for him a representation, in whatever he has made his own, there has language penetrated.... So much is logic natural to the human being, is indeed his very nature. (W 5:20/SL I 2)

As the argument of the Preface continues, it becomes clear that the "forms of thought" are regarded by Hegel, as we have seen, both as contentful (so not merely formal) and as (potentially) objective: some forms of thought are capable of saying how things essentially are. ${ }^{6 r}$ Since Hegel evidently thinks the forms of thought are also the source of metaphysical concepts, he here implies that metaphysical concepts are also "set out and stored in human language." This would be trivial if it meant only that metaphysical concepts were contained in the vocabulary of a language. It is a commonplace that metaphysical concepts often begin (at least historically) as ordinary words. The claim has more weight if metaphysical concepts are linked to language as used. ${ }^{62}$ And language as used comes in the form of

${ }^{60}$ For some readers, it may be helpful to see a similar view put forth in contemporary terms by Stephen Schiffer in "Language-Created Language-Independent Entities." Schiffer argues that some contentious metaphysical concepts like $<$ property $>$ or $<$ proposition $>$, though not themselves linguistic entities, are discovered or invented through "pleonastic transformations" on linguistic entities. A pleonastic transformation involves an expressive rather than substantive change from a first-order claim. Schiffer introduces the notion to show that there is nothing to be feared from a commitment to abstract entities like properties. For from the claim that the ball is red, I can derive the property redness through a pleonastic transformation. As long as one realizes that redness is just an expressive transformation on one's commitment to a ball's being red, there is no reason to deny the existence of properties. But there is nothing in this commitment to properties not implicit in the use of the original sentence. For a further development of Schiffer's view of pleonastic transformations, see Thomasson, "Easy Ontology."

${ }^{6}$ See W 5:26/SL I6: "the nature, the specific essence, that which is truly permanent and substantial in the manifold and accidentality of appearance and fleeting externalization, is the concept of the thing." Yet Hegel also thinks that isolated focus on individual concepts will often show them to be faulty: "When the thought determinations which are only external forms are seriously considered in themselves, the result can only be the demonstration of their finitude and of the untruth of their supposed being-for-itself, and that the concept is their truth" (W 5:30/SL I9).

${ }^{62}$ To this extent, I agree with Pippin's recent emphasis that Hegel's Logic is based in thinking and not only thoughts (see Shadows, 20-2I, chap. 3). However, Pippin believes that the movement of the Logic depends on the role of self-conscious thinking in unifying the determinations of the Logic: "The movement of pure thought is like a movement in a proof, on the assumption that the moves are inferences a thinker, on pain of contradiction, must make, and not merely formal-structural functions, as in a symbolic logic" (Shadows, I32). By contrast, I think we can explain the relevance of "thinking" simply in terms of the content implicit in judgments and syllogisms. See $E L \S$ I9R, where Hegel states that thinking (Denken) gives "laws and determinations" to itself. The content of logic "is nothing but our own thinking and its ordinary determinations. They are also what we are most familiar with: being, 
judgments. I have argued that for Hegel, judgments come with different logical content. On this view, if metaphysical concepts are stored and set out in human language, it is because these concepts supervene on the variety of logical contents involved in the judgmental and inferential acts of human speech. ${ }^{63}$

I am thus linking Hegel's claim about the connection of "categories" or "forms of thought" to language to his further claim about the dependence of the Objective on the Subjective. For while it is true enough that the concepts of the Objective Logic are, or correspond to, German words, only the Begriffslogik treats concepts as they figure in language as it is used: in judgments and in syllogisms. This thesis adumbrates an interpretive program that I can only mention here, but not complete: to determine for every concept of the Objective Logic its foundation in the Subjective Logic. This program is implied in the truth of the supervenience thesis. Short of embarking on a commentary, in the next section I will give a few further examples of the thesis in action. The examples are rather unsystematic because Hegel's own references to the supervenience thesis are themselves unsystematic. But from some relatively clear cases, I hope a pattern can emerge.

\section{FURTHER EXAMPLES OF THE SUPERVENIENGE THESIS}

Following the "positive judgment," which we have already treated, Hegel moves on to discuss the "negative judgment," which begins with the content: "The singular is not the universal." There are a number of allusions to Hegel's earlier treatment of nonbeing in this section. Just as negation provides a limit to an existent (Dasein) in the Doctrine of Being, so here the negation in a negative judgment delimits the particular quality of a singular thing by denying certain universal properties to it. The notion of particulars (delimited universals) depends essentially on negation. After arriving at the connection of negation and particularity, Hegel again alludes to the objective meaning of such judgments: "This judgment is according to its objective meaning only the moment of the alteration of accidents, or, in the sphere of existence [Dasein], of the singularized properties [Eigenschaften] of the concrete. Through this alteration, the complete determinateness of the predicate, or the concrete, emerges as posited" (W 6:322/SL 566, translation modified). While Hegel accounts for the concept <quality $>$ in the positive judgment, he here suggests that the concept $<$ singularized properties $>$ comes from the negative judgment, since that logical content introduces particularity. This is significant, since it follows a similar pattern that Hegel mentions earlier in the Objective Logic: "Quality is the immediate determinateness of something.... The property of the thing is, for its part, the negativity of reflection, by virtue of which concrete existence in general is a concrete existent" (W 6:I33/SL 426). Thus, while the simple concept

nothing, etc.; determinacy, magnitude, etc.; being-in-itself, being-for-itself, one, many, and so on. But this familiarity only tends to make the study of Logic more difficult" (W 8:67/EL §I9R). I think we are "most familiar" with these concepts because of the way they can be involved in the differentiation of logical content. See likewise Brandom, Spirit, 209, where logical content is treated in terms of pragmatics.

${ }_{63}^{63}$ "They [i.e. forms of spirit] come up in the speech of everyday, mingled and wrapped in crude concrete [instances], for example, in 'The tree is green.' 'Tree' and 'green' are what controls our representation. We do not in ordinary life reflect on the 'is,' we do not set this pure being in relief, make it our ob-ject, as philosophy does. But this being is here present and expressed" (EL, "Introduction," xvi). 
$<$ quality $>$ supervenes on the role of the predicate in the positive judgment, the concept $<$ property $>$ (which introduces a greater level of concreteness) supervenes on the role of the predicate in judgments of particularity, which introduce logical negation. ${ }^{64}$ A change in the logical content of judgments involves a change in the relevant metaphysical concepts.

The positive and negative judgments are both discussed in "The Judgment of Existence"; they show the supervenience of concepts from the Doctrine of Being. Hegel later shows how the key concepts from the Doctrine of Essence supervene on logical content in "The Judgment of Reflection." In judgments of this type, the subject is treated as something "existing and appearing [das Existierende und Erscheinende]" (W 6:328/SL 570, translation modified), while the predicate is "the essential" or "reflected in-itselfness" (W 6:327/SL 569, translation modified). These, of course, are central distinctions from the Doctrine of Essence. Hegel makes it clear that they are characterizations of the objective meaning of judgments of reflection (W 6:328/SL 570). Yet he suggests that these new objective meanings of the terms in the judgment depend on a new logical significance of the subject and predicate in them: "In the judgment that has now arisen [i.e. of reflection], the subject is a singular as such; and similarly, the universal is no longer an abstract universality, or a singular property, but is posited as a universal that has collected itself together into a unity through the connection of different terms" (W 6:326/ $S L$ 568). Though judgments of reflection can have the same superficial form as judgments of existence, they differ in the weight they give to the predicate. For example, the "singular judgment," even as a judgment of reflection, has the same basic logical structure as the positive judgment: "the singular is universal." But Hegel says that the singular judgment places weight on the predicate as something essential to the subject, so that the logical content can be more correctly stated: "this [i.e. singular] is an essential universal" (W 6:328/SL 570). The culmination of this type of judgment is one in which a "kind" (Gattung) is predicated of a subject (W 6:330/SL 57I). Genus-concepts have a different logical relation to subjects than predicates from positive judgments, Hegel contends: "The genus does not inhere in the subject; it is not one property of it or a property at all; it contains all singular determinacies dissolved in its substantial purity" (W 6:333-34/SL 574). Only by this logical relation between genus-concepts and correlated subjects is the metaphysical relation of essentiality expressed. Once again, Hegel maintains that the new objective meaning of this type of judgment is connected to a change in its logical content. Even subtle changes in the inflection of logical content are shown to have significance for the metaphysical content of a judgment.

In moving on to discuss "The Judgment of Necessity," the next major division, Hegel offers one of his clearest allusions to the connection between the account of judgment and the Objective Logic. He writes, "The determination to which

${ }^{64}$ One should note that, despite Hegel's explicit mention of "property" (Eigenschaft), which is discussed in the Doctrine of Essence, it seems more fitting that $<$ determination $>$ or $<$ constitution $>$ would be the supervenient concept in the Doctrine of Being following "quality" (see W 5:I3I/SL 95). It is possible that Hegel erred against his own vocabulary here. However, I am not seeking to evaluate the appropriateness of each case, only to show the pattern that Hegel thinks some metaphysical concept supervenes on each logical form. 
universality has advanced is, as we have seen, the universality that is in and for itself or the objective universality, which in the sphere of essence corresponds to substantiality" (W 6:335/SL 575, translation modified). ${ }^{65}$ Hegel again uses the weak term "corresponds" to describe the relation between the Objective and Subjective Logic. I think we are permitted to strengthen the connection by positing the concept $<$ substantiality $>$ as supervening on the judgment of necessity. We see this, I believe, as Hegel describes one of the subtypes of the judgment of necessity, the hypothetical judgment. Hegel says that the hypothetical judgment connects "two immediate, or externally contingent concrete existences" to each other with necessity (W 6:337/SL 576). This sort of judgment entails several concepts Hegel describes in the Doctrine of Essence:

The hypothetical judgment can be more precisely determined in terms of the relationships of reflection as a relation of ground and consequence, condition and conditioned, causality etc. Just as substantiality is in the categorical judgment in the form of the concept, so is the connection of causality in the hypothetical judgment. This and the other relations all [sämtlich] stand under it [i.e. the form of the concept], but they are here no longer as independent sides, but rather in this relation essentially only as moments of one and the same identity. (W 6:338/SL 577, translation modified)

Hegel says that causality is "in" the hypothetical judgment as substantiality is "in" the categorical. This sounds stronger than a mere "correspondence," as he sometimes calls the relation between the Doctrines of Essence and Concept. The hypothetical judgment explains <causality $>$.

Moreover, this passage authorizes us to generalize from Hegel's explicit references to the Objective Logic; he says that "all" (sämtlich) the relations of essence stand "under" the form of the concept. Presumably, this means that the possibility of assigning every concept of the Doctrine of Essence to some form within the Begriffslogik is anticipated. Or in our terms, every concept from the Doctrine of Essence (and Being, a fortiori) supervenes on some logical relation within the Doctrine of the Concept. Thus, this small sample of cases seems to indicate a pattern underlying Hegel's Logic as well as his conviction about the origin of metaphysical concepts.

\section{C O N G L U S I O N}

In the above, I have tried to show that Hegel's account of logical forms, which may otherwise appear as a tortuous derivation of forms of judgment and inference, plays a significant role in Hegel's view that "logic" replaces metaphysics. It is not merely that metaphysical concepts are "forms of thought" (Denkformen) in the innocent sense that they make up the most elementary structure of our conceptual thought. This claim would not have been denied by the pre-Kantian metaphysics that Hegel's Logic is meant to replace. Instead, Hegel works out a more ambitious attempt than even Kant's to connect metaphysical concepts to an origin in specific logical forms. He can do this thanks to a richer conception of logical form or

\footnotetext{
${ }^{65}$ Compare the Encyclopedia account: "The categorical judgment ('Gold is a metal,' 'The rose is a plant') is the immediate judgment of necessity, and corresponds to the relationship of substantiality

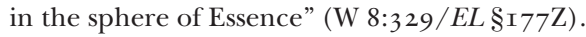


content. Though the logical forms would be merely empty if the Kantian picture of general logic held sway, Hegel feels entitled to ascribe this new significance to the logical forms because he shows that the forms of judgment and inference have logical content, produced from the varying role of singular, particular, and universal terms within them: "This formal discipline must therefore be thought of as inherently much richer in determinations and content, and also of infinitely greater efficacy over the concrete, than it is normally taken to be" (W 6:267-68) SL 524-25). Yet previous interpretations of the Logic have not much clarified the "infinitely greater efficacy" that the formal discipline of logic is supposed to have: thanks to logical content, judgmental forms can be seen to express an "objective meaning" that is the source of metaphysical concepts.

Rather than considering the question of Hegel's view of the relation of thought and being, I have here restricted my attention to a question internal to Hegel's Logic: the relation of logical forms and metaphysical concepts. ${ }^{66}$ Since the supervenience thesis explains the origin of metaphysical concepts without itself explaining which are true, answering the latter question does not suffice to answer the former. Indeed, the supervenience thesis often explains precisely why metaphysical concepts are untrue, or inadequate for an explanation of how things are. Though we may be owed an account of how the "pure thought" of Hegel's Logic is able also to say how things are, I think there is a separate value in exploring the conceptual questions, as done in this paper. For, if correct, the supervenience thesis should hold despite interpretive disagreements on the metaphysical "status" of Hegel's Logic. ${ }^{67}$ For example, and at the extremes, it could hold whether Hegelian thought (and thus logical content) is of squarely human or Platonistic, or otherwise theological, provenance. ${ }^{68}$ Moreover, the present model helps avoid the supposed conflict between accounts that argue about whether Hegel thinks his forms of thought are also forms of "being" or "any possible object of judgment." Both these options require that Hegel's forms of thought be taken at face value as being suitable for expressing how things are in an unqualified manner. ${ }^{69}$ But I have shown that embedded in Hegel's account of logical forms is a restatement and further explanation of his critique of traditional metaphysics in the Objective Logic. This does not mean that Hegel sees no positive use for

${ }^{6}$ Pippin, Shadows, 46-48, seems to make this identification of the two issues.

${ }^{67} \mathrm{Hegel}$ allows something much like this in his I8 82 report to Niethammer. He writes that the Denkformen he discusses "are independent of metaphysical system; they occur in transcendental idealism as well as in dogmatism; the former calls them determinations of entium, the latter [determinations] of the understanding" (W 4:407). In other words, the same metaphysical concepts can occur, and be subject to criticism, regardless of metaphysical commitment.

${ }^{68} \mathrm{My}$ own tendency is to avoid transcendent entities in explaining Hegelian thought. See Wolf, "Rethinking Hegel's Conceptual Realism."

${ }^{69}$ Pippin's recent claim that the Logic "is, or at least appears to be, something like an account of all possible account-givings" (Shadows, 32) seems to assume that Hegel generally attempts to offer a positive and correct account of account-givings. Likewise when he writes, "Since these metaconcepts [of the Logic] are the forms of whatever can be truly said, and what is truly said is what is the case, they are the forms of reality" (Shadows, II I). I see no evidence for the completeness implied in Pippin's claims: "all possible account-givings" and "whatever can be truly said." Though Pippin acknowledges the critical task of the Objective Logic (e.g. Shadows, 33-34), I do not see how this acknowledgement squares with his general characterization of the work, since it is unclear from his account how the Subjective Logic would complete the task the Objective Logic fails to achieve. 
metaphysical concepts. Indeed, the goal of the Subjective Logic is also to restore a proper use to some of the concepts of the Objective Logic. ${ }^{70}$ Nevertheless, the critical side of his account prevents a complacent evaluation of metaphysical concepts. We should not ask what the relation of thought to being is simpliciter, but rather how and to what extent the forms of thought-now taken specifically as forms of concepts, judgment, and syllogism—are suited to express the truth. ${ }^{7}$

\section{B I B L I O G R A P H Y}

Anderson, R. Lanier. The Poverty of Conceptual Truth: Kant's Analytic/Synthetic Distinction and the Limits of Metaphysics. Oxford: Oxford University Press, 2015.

Baumgarten, Alexander. Metaphysics: A Critical Translation with Kant's Elucidations, Selected Notes, and Related Materials. Translated and edited by Courtney D. Fugate and John Hymers. London: Bloomsbury, 2013.

Beiser, Frederick C. Hegel. New York: Routledge, 2005.

Bowman, Brady. Hegel and the Metaphysics of Absolute Negativity. Cambridge: Cambridge University Press, 2013.

Brandom, Robert. "Metaphilosophical Reflections on the Idea of Metaphysics." Philosophia 4 O (2OI 2): I3-26.

- A Spirit of Trust: A Reading of Hegel's Phenomenology. Cambridge, MA: Harvard University Press, 2019.

Bubner, Rüdiger. The Innovations of Idealism. Translated by Nicholas Walker. Cambridge: Cambridge University Press, 2003.

- Zur Sache der Dialektik. Stuttgart: Reclam, I980.

Cirullo, Franco. Hegel's Critique of Essence: A Reading of the Wesenslogik. London: Routledge, 2006.

Dummett, Michael. Frege: Philosophy of Language. 2nd ed. Cambridge, MA: Harvard University Press, I98 I.

Erdmann, Johann Eduard. Leibnitz und die Entwicklung des Idealismus vor Kant. Leipzig: Vogel, I 842.

Frege, Gottlob. The Frege Reader. Edited by Michael Beaney. London: Blackwell, I997.

. Wissenschaftlicher Briefwechsel. Hamburg: Felix Meiner, 1976.

Gerhard, Myriam. Hegel und die logische Frage. Berlin: De Gruyter, 2015.

Hanna, Robert. "From an Ontological Point of View: Hegel's Critique of the Common Logic." Review of Metaphysics 40 ( I986): 305-38.

Hegel, G. W. F. The Encyclopaedia Logic: Part I of the Encyclopaedia of the Philosophical Sciences with the Zusätze. Translated by T. F. Geraets, W. A. Suchting, and H. S. Harris. Indianapolis: Hackett, I99I. [EL]

- Gesammelte Werke. 3 I vols. Edited by the Nordrhein-Westfälischen Akademie der Wissenschaften und der Künste, in cooperation with the Deutsche Forschungsgemeinschaft. Hamburg: Meiner, I968-. [GW]

- Hegel: The Letters. Translated by Clark Butler and Christiane Seiler. Bloomington: Indiana University Press, I984.

- The Phenomenology of Spirit. Translated by Michael Inwood. Oxford: Oxford University Press, 20I 8. [PS]

- The Science of Logic. Translated and edited by George di Giovanni. Cambridge: Cambridge University Press, 20IO. [SL]

- Werke in zwanzig Bänden. Edited by Eva Moldenhauer and Karl Markus Michel. Frankfurt: Suhrkamp Verlag, I970. [W]

Hintikka, Jaakko. Logic, Language Games, and Information: Kantian Themes in the Philosophy of Logic. Oxford: Clarendon Press, I973.

Houlgate, Stephen. The Opening of Hegel's Logic. West Lafayette, IN: Purdue University Press, 2006.

Kant, Immanuel. Critique of Pure Reason. Translated and edited by Paul Guyer and Allen Wood. Cambridge: Cambridge University Press, I998.

${ }^{70}$ I discuss this possibility further in Wolf, "Rethinking Hegel's Conceptual Realism."

${ }^{71}$ I would like to thank the two anonymous reviewers for their helpful suggestions and criticisms of this paper. Thanks also to Sebastian Luft, Yoon Choi, Michael Monahan, and Karin de Boer for discussion and feedback on an earlier iteration of these ideas. 
- Jäsche Logic. In Kant, Lectures on Logic, translated and edited by J. Michael Young, 52 I-640. Cambridge: Cambridge University Press, I992.

. Kants gesammelte Schriften. 29 vols. Edited by the Berlin-Brandenburgische Akademie der Wissenschaften. Berlin: De Gruyter, I900-.

- Metaphysik Mrongovius. In Kant, Lectures on Metaphysics, translated and edited by Karl Ameriks and Steve Nargon, I09-286. Cambridge: Cambridge University Press, I997.

Kim, Jaegwon. Mind in a Physical World: An Essay on the Mind-Body Problem and Mental Causation. Cambridge, MA: MIT Press, I998.

Koch, Anton Friedrich. Die Evolution des logischen Raumes. Aufsätze zu Hegels Nichtstandard-Metaphysik. Tübingen: Mohr Siebeck, 20I4.

Lau, Chong-Fuk. "The Aristotelian-Kantian and Hegelian Approaches to Categories." Owl of Minerva 40 (2008): 77-I I4.

- Hegels Urteilskritik. Systematische Untersuchungen zum Grundproblem der spekulativen Logik. Munich: Wilhem Fink Verlag, 2004.

McLaughlin, Brian, and Karen Bennett. "Supervenience." In Stanford Encyclopedia of Philosophy. Stanford University, I997-. Article published July 25, 2005; last modified January IO, 20I 8. https:/ / plato. stanford.edu/archives/win20I 8 /entries/supervenience/.

McTaggart, J. M. E. A Commentary on Hegel's Logic. Cambridge: Cambridge University Press, I9 Io.

Meier, Georg Friedrich. Metaphysik. Vol. I. Halle: J. J. Gebauer, I75 5.

Pippin, Robert B. Hegel's Idealism: The Satisfactions of Self-Consciousness. Cambridge: Cambridge University Press, I989.

- Hegel's Realm of Shadows: Logic and Metaphysics in The Science of Logic. Chicago: The University of Chicago Press, 2018.

Redding, Paul. Analytic Philosophy and the Return of Hegelian Thought. Cambridge: Cambridge University Press, 2007.

—. "The Relation of Logic and Ontology in Hegel." In Categories of Being: Essays on Metaphysics and Logic, edited by Leila Haaparanta and Heikki J. Koskinen, I45-66. Oxford: Oxford University Press, 2012.

—. "The Role of Logic 'Commonly So Called' in Hegel's Science of Logic." British Journal for the History of Philosophy 22 (20I4): 28I-3OI.

—. "Subjective Logic and the Unity of Thought and Being: Hegel's Logical Reconstruction of Aristotle's Speculative Empiricism." Internationales Jahrbuch des Deutschen Idealismus I 2 (2017): I $65-88$.

Rosen, Stanley. The Idea of Hegel's Science of Logic. Chicago: The University of Chicago Press, 20 I 4.

Russell, Bertrand. "Mathematical Logic as Based on the Theory of Types." In From Frege to Gödel: A Source Book in Mathematical Logic, I 879-I93 I, edited by Jean van Heijenoort, I 50-82. Cambridge, MA: Harvard University Press, I967.

Sans, Georg. Die Realisierung des Begriffs. Eine Untersuchung zu Hegels Schlusslehre. Berlin: Akademie Verlag, 2004.

Schick, Friedrike. "Begriff und Mangel des formellen Schliessens. Hegels Kritik des Verstandesschlusses." In Der Begriff als die Wahrheit: Zum Anspruch der Hegelschen "Subjektiven Logic," edited by Anton Friedrich Koch, Alexander Oberauer, and Konrad Utz, 85-Ioo. Paderborn: Verlag Ferdinand Schöningh, 2003.

- Hegels Wissenschaft der Logik—metaphysische Letztbegründung oder Theorie logischer Formen? Freiburg and Munich: Verlag Karl Alber, I994.

—. "Die Lehre vom Begriff. Erster Abschnitt. Die Subjectivität." In Kommentar zu Hegels Wissenschaft der Logik, edited by Michael Quante and Nadine Mooren, 457-5 58. Hamburg: Felix Meiner, 20 I 8.

Schiffer, Stephen. "Language-Created Language-Independent Entities." Philosophical Topics 24 (I996): I $49-67$.

Stekeler-Weithofer, Pirmin. Kritik der reinen Theorie. Logische Differenzen zwischen Wissenschaft und Weltanschauung. Tübingen: Mohr Siebeck, 2018.

Stern, Robert. Hegel, Kant, and the Structure of the Object. London: Routledge, I 990.

. Hegelian Metaphysics. Oxford: Oxford University Press, 2009.

Taylor, Charles. Hegel. Cambridge: Cambridge University Press, I 975.

Theunissen, Michael. Sein und Schein: Der kritische Funktion der Hegelschen Logik. Frankfurt am Main: Suhrkamp Verlag, I978.

Thomasson, Amie. "Easy Ontology and Its Consequences." In Meaning and Other Things: Themes from the Work of Stephen Schiffer, edited by Gary Ostertag, 34-53. Oxford: Oxford University Press, 2016.

Wolf, W. Clark. "Rethinking Hegel's Conceptual Realism." Review of Metaphysics 72 (20I 8): 33 I-70. 
298 JOURNAL OF THE HISTORY OF PHILOSOPHY 59:2 APRIL 202 I

Wolff, Christian. Vernünftige Gedanken von den Kräften des menschlichen Verstandes und ihrem richtigen Gebrauche in Erkenntnis der Wahrheit. In Wolff, Gesammelte Werke, vol. I, edited by Hans Werner Arndt. Hildesheim: Georg Olms, I965 (orig. I7I3).

Wolff, Michael. Abhandlung über die Prinzipien der Logik. 2nd ed. Frankfurt am Main: Vittorio Klostermann, 2009.

. "Science of Logic." In The Bloomsbury Companion to Hegel, edited by Allegra de Laurentiis and Jeffrey Edwards, 7I-IO2. London: Bloomsbury, 20I3. 